Article

\title{
Practical Synthesis of Quinoline-Protected Morpholino Oligomers for Light-Triggered Regulation of Gene Function
}

\author{
Davide Deodato ${ }^{1, *(1)}$ and Timothy M. Dore ${ }^{1,2, *(D)}$ \\ 1 New York University Abu Dhabi, PO Box 129188, Abu Dhabi, UAE \\ 2 Department of Chemistry, University of Georgia, Athens, GA 30602, USA \\ * Correspondence: davide.deodato@nyu.edu (D.D.); timothy.dore@nyu.edu (T.M.D.)
}

Academic Editors: Fawaz Aldabbagh and Sven Mangelinckx

Received: 15 March 2020; Accepted: 22 April 2020; Published: 29 April 2020

\begin{abstract}
Photoactivatable cyclic caged morpholino oligomers (ccMOs) represent a promising tool to selectively regulate gene expression with spatiotemporal control. Nevertheless, some challenges associated with the preparation of these reagents have limited their broader use in biological settings. We describe a novel ccMO design that overcomes many of the challenges and considerably expedites the synthetic preparation. The key factor is the introduction of an ethynyl function on the photocleavable linker to facilitate the use of a Huisgen 1,3-dipolar cycloaddition for the coupling reaction with the oligonucleotide. Compared to previous strategies, this modification reduces the number of synthetic steps and significantly improves the total yield and the stability of the linker. We used the alkynyl-functionalized linker for the preparation of two different ccMOs targeting the mRNA of the glutamic acid decarboxylase genes, gad1 and gad2. HPLC analysis confirms that the caging strategy successfully inhibits the DNA binding ability, and the activity can be restored by brief illumination with 405-nm light. Overall, the straightforward preparation together with the clean and fast photochemistry make these caged antisense reagents excellent tools to modulate gene function in-vivo with spatial and temporal precision.
\end{abstract}

Keywords: photoactivation; photo-uncaging; antisense reagents; morpholino oligomers; ccMO; click chemistry

\section{Introduction}

Antisense reagents represent powerful tools used to selectively modify the expression of a gene of interest, avoiding the use of labor-intensive gene knockout techniques. Among the various classes of reagents developed so far, phosphorodiamidate morpholino oligomers (MOs) [1] are an interesting and successful example. Unlike other antisense reagents, MOs possess a neutral backbone made of morpholino rings interconnected through phosphorodiamidate bonds. This "unnatural" structure gives them several advantages, such as cost-effective preparation, high binding affinity, stability to nuclease degradation, and high aqueous solubility [2-4]. These properties often make MOs the reagent of choice for in vitro and, especially, in vivo gene knockdown experiments [5-8].

Nevertheless, the injection of MOs causes immediate and organism-wide gene silencing, precluding the use of these tools for the stage- or tissue-selective studies. This issue has been addressed with the introduction of photoactivatable (or "caged") versions (cMOs) [9], where the MO is covalently attached to a photoremovable protecting group (PPG) that masks its activity. The activity can be restored by light exposure, which represents an ideal exogenous stimulus because it causes minimal damage to the cell or organism and is simple to use. Different strategies have been used to design efficient photoactivatable MOs. Earlier work used an MO [9-11] or RNA [12] complementary inhibitor sequence 
(containing a photocleavable moiety) to bind to the morpholino by Watson-Crick base pairing and suppress its activity. Irradiation at 360-365 nm resulted in the separation of the inhibitor sequence and exposure of the $\mathrm{MO}$ active sequence. Another strategy employed cMOs containing multiple nucleobases protected with a nitrobenzyl-based PPG, which were subsequently uncaged upon UV irradiation (25 W lamp) [13]. Despite the relative success of these approaches, they still suffer several limitations, including challenging and laborious synthesis, the requirement of high-power UV light for complete photolysis, and the presence of background activity from the caged sequence.

Many of these issues were resolved with the development of cyclic caged morpholino oligomers (ccMOs) [14-19], where the oligo is cyclized using a photocleavable linker between the two ends of the sequence (Figure 1). End-to-end circular oligonucleotides have already been described [20], and photolabile versions have successfully been employed for the photoactivation of various types of oligos, including DNA [21], DNAzyme [22], miRNA [23], and siRNA [24]. In the case of MOs, it has been shown that forcing the sequence into a closed ring decreases the RNA hybridization ability by more than four-fold [15] until linearization, triggered by light exposure, restoring the active morpholino. This strategy has several advantages, such as: (1) easier synthesis, because it does not require the preparation of the complementary inhibitory sequence; (2) a simpler purification step since the circular MO is easily separated by HPLC from the unreacted linear sequences; (3) the absence of off-target effects, because the protecting strategy relies on covalent modification instead of Watson-Crick base pairing. As a result, various ccMOs have been developed and successfully used to regulate gene function with spatiotemporal precision. The Chen and Tang labs independently designed the first examples of ccMOs and successfully applied the strategy for selective control of gene function in zebrafish embryos [14,15]. Sequential gene knockdown was achieved by employing wavelength-selective ccMOs, in which two orthogonal PPGs (nitrobenzyl- and coumarin-based) were used to cage different sequences [16]. Dmochowski et al. developed ruthenium-caged circular MOs targeting the mRNA of the chordin and notail zebrafish genes, achieving efficient gene silencing with 450-nm irradiation [18].

Inspired by such work, we designed a ccMO using the highly efficient 8-bromo and 8-cyano-7hydroxyquinolinyl-methyl (BHQ and CyHQ) PPGs and applied the strategy to the photoactivation of MO sequences targeting the mRNA of the glutamic acid decarboxylase genes ( gad1 and gad2) of zebrafish [19]. We successfully employed these tools to bypass glutamic acid decarboxylase (GAD)-induced morphological defects and study the effects of GABAergic transmission during brain development. The main advantages of these ccMOs were their stability toward spontaneous and enzyme-catalyzed degradation and the possibility to carry out the photolysis reaction with ambient light, due to the favorable properties of the PPGs [25]. One disadvantage was that the synthesis of the linker moiety, inspired by Chen's work [14], required multiple moderate-to-low yielding steps, which limited the practicality of these ccMOs.
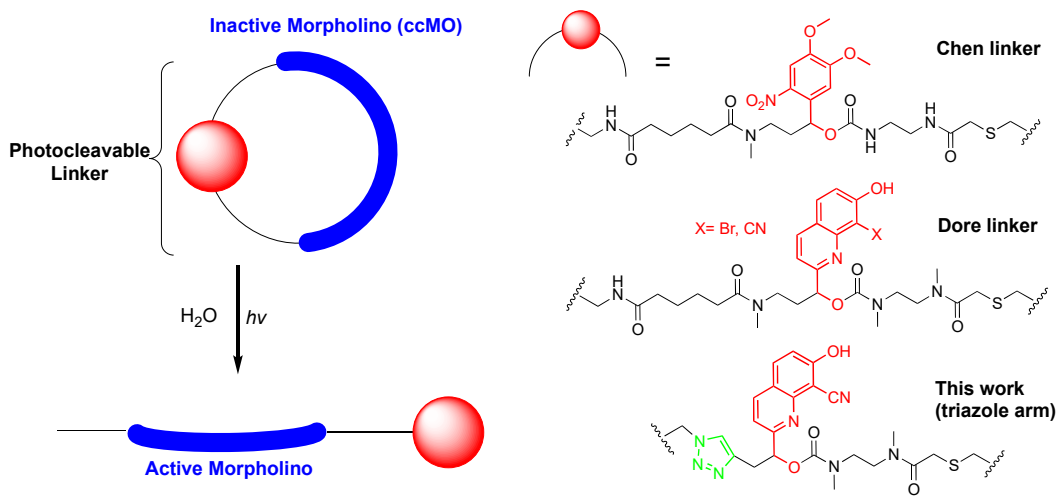

Figure 1. Schematic representation of the photoactivatable cyclic caged morpholino oligomers (ccMO) activation strategy. Structures of the photocleavable linkers described in the literature and the linker developed in this work. Photoremovable protecting groups (PPGs) are depicted in red. 
In this work, we introduced a novel cyclic caged $\mathrm{MO}$ with a different linker, which significantly expedited the synthetic preparation while retaining all the other excellent properties, including a fast and clean photolysis reaction with complete restoration of the oligonucleotide binding ability.

\section{Results}

\subsection{Design and Synthesis of the Linker Moiety}

The previous linkers reported by Chen [14] and Dore [19], consisted of a photocleavable unit (nitrobenzyl- or quinoline-based) bearing two arms with selected functionalities in order to be connected to the $5^{\prime}$ and $3^{\prime}$ ends of the MO sequence (Figure 1). The synthesis of these molecules (starting from the benzaldehyde precursor) required a sequence of 11 steps for Chen's and nine steps for Dore's linker (CyHQ case), with total yields of $8 \%$ and 5\%, respectively. The challenging and laborious nature of their syntheses is one of the main reasons behind the sparse application of ccMOs in biological studies.

With the aim of facilitating the synthetic preparation, we designed a new CyHQ-based linker (compound 4, Scheme 1) bearing a simple propargyl unit on one of the arms, which can be connected to an azide-functionalized MO via Huisgen 1,3-dipolar cycloaddition, a click chemistry reaction. This strategy reduced the overall number of steps by avoiding the low-yielding preparation of the adipoyl amide arm (Figure 1, Chen and Dore linker) and improved the efficacy of MO coupling by exploiting the Huisgen 1,3-dipolar cycloaddition, a simple, efficient and water-favorable "click" chemistry reaction [26]. The synthetic pathway leading to linker 4 starts from benzaldehyde MOM-CyHQ-CHO (Scheme 1), obtained in multi-gram quantities according to the method previously reported [27]. The propargyl appendage was installed via a Barbier reaction using 1,2-dibromoethane as the activator under ultrasound stirring, affording secondary alcohol 1. The second arm of the linker was prepared by coupling the activated imidazolyl carbamate, generated after reacting 1 with $1,1^{\prime}$-carbonidiimidazole, with $\mathrm{N} \mathrm{N}^{\prime}$-dimethylethylenediamine, furnishing compound $\mathbf{2}$ in good yield (57\% over two steps). The latter was reacted with chloroacetyl chloride obtaining $\alpha$-activated amine 3 , which was deprotected from the acid-labile MOM group with trifluoroacetic acid in $\mathrm{CH}_{2} \mathrm{Cl}_{2}$, furnishing final compound 4 .

The total yield for the preparation of the new linker was $28 \%$ over five steps, representing a 5.6-fold improvement from the previous methodology (Dore's linker). In addition, the stability of the final linker is improved by substituting the moisture-sensitive succinimidyl ester present in Chen's and Dore's linkers, with the terminal alkyne. As a result, linker 4 is bench-stable (if kept in the dark), whereas the previous versions require storage at $-30{ }^{\circ} \mathrm{C}$ under an inert atmosphere.

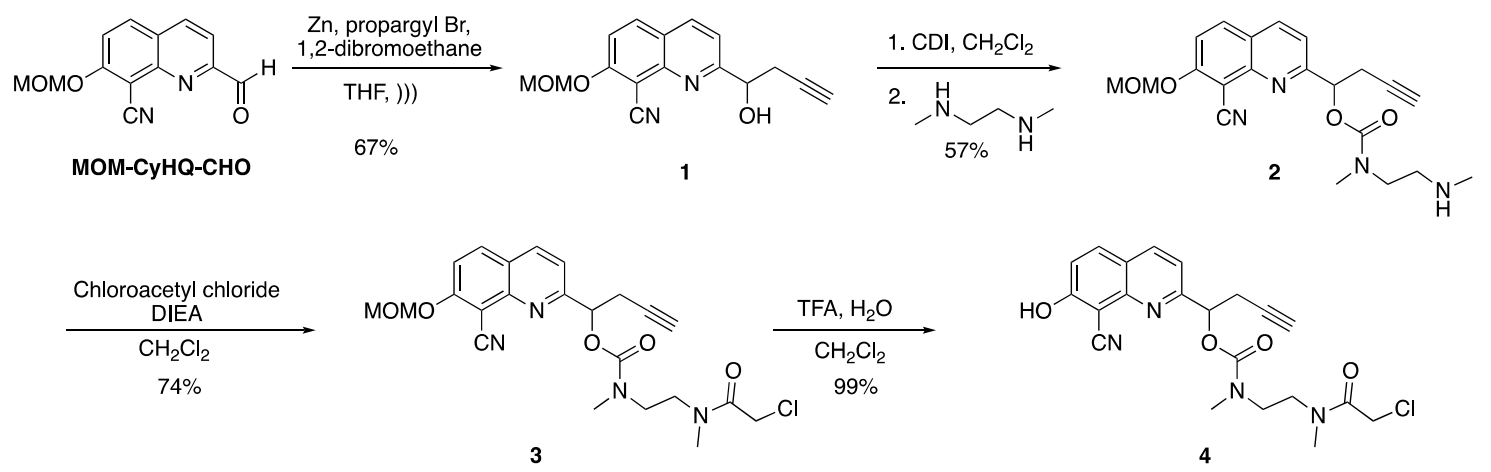

Scheme 1. Synthesis of linker 4 starting from MOM-СyHQ-CHO [27].

\subsection{MO Coupling and Final Cyclization}

As a proof of concept, we selected the same MO sequences used in our previous work [19] (targeting the mRNA of the gad1 and gad2 genes), to be photocaged with the new linker 4 . In this case, the linear MO (5a-b, Scheme 2) contained an azide functionality on the $5^{\prime}$ end, to be coupled to the 
linker through a click chemistry reaction, and a disulfide amide modification on the $3^{\prime}$ end for the ultimate macrocyclization.
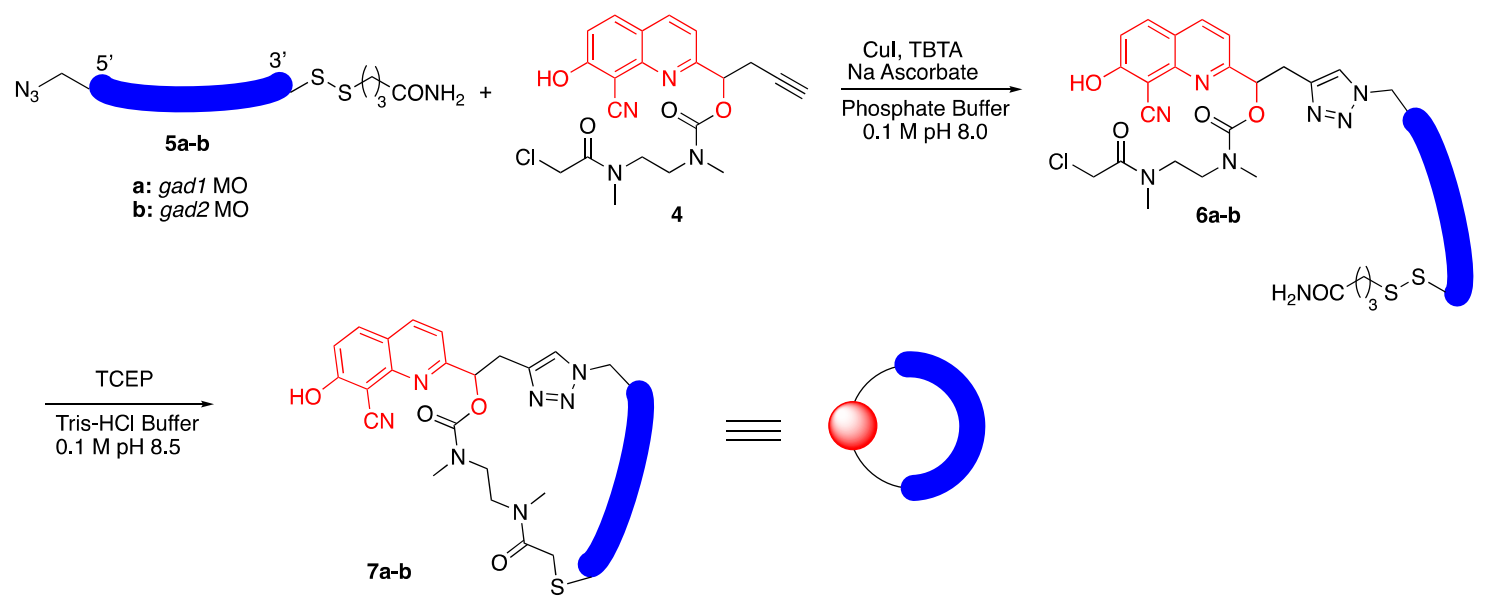

Scheme 2. Synthesis of ccMOs $7 \mathbf{a}-\mathbf{b}$.

Final ccMOs 7a-b were prepared according to the two-step procedure given in Scheme 2. The coupling reaction between 4 and $\mathbf{5 a - b}$ was achieved via Huisgen 1,3-dipolar azide-alkyne cycloaddition, using copper iodide as a catalyst in phosphate buffer. Tris[(1-benzyl-1H-1,2,3-triazol-4-yl)methyl]amine (TBTA) was used as a $\mathrm{Cu}(\mathrm{I})$ stabilizer and sodium ascorbate as a reducing agent. Under these conditions, the reaction was completed within two hours after shaking the reaction mixture with a vortex at room temperature in the dark. The final macrocyclization was achieved by the treatment of $\mathbf{6 a}-\mathbf{b}$ with a freshly prepared solution of tris(2-carboxyethyl)phosphine hydrochloride in Tris buffer. The in-situ generated sulfhydryl performed a nucleophilic substitution on the activated $\alpha$-carbonyl, affording the ccMOs 7a-b in moderate yields (25-42\% over two steps, determined by UV analysis). Purification was carried out by size exclusion chromatography (on a NAP-5 column, eluting with water), and the final compounds were characterized by LC-MS analysis (see the Materials and Methods). The full structures of $\mathbf{7 a -} \mathbf{b}$ are given in the Supplementary Material (Figure S1).

The photolysis reaction was investigated by irradiating aqueous solutions of 7a with 405-nm light for $30 \mathrm{~s}$ using an LED source, monitoring the reaction by LC-MS before and after irradiation, using an electrospray ionization (ESI) source (Figure 2). The mechanism of the photolysis reaction of quinoline-based PPGs is well known [28] and proceeds with the generation, after excited-state C-O bond cleavage, of a benzylic carbocation that is rapidly quenched by the solvent, resulting in a hydroxy species. In the case of a carbamate derivative like 7a [19,29], an additional decarboxylation reaction occurred with the formation of the corresponding amine 8a (Figure 2). The net molecular weight loss of the process was $26 \mathrm{~m} / z$, as confirmed by the MS analysis. The MS trace of 7a before UV irradiation (Figure 2, top panel) showed peaks corresponding to multi-charge ionization states of the MO, and the deconvoluted spectrum confirmed the molecular weight of 7a. Note that the small peak identified at $8956 \mathrm{~m} / \mathrm{z}$ corresponds to a ccMO missing one nucleotide, an impurity also found in the commercial starting material 5a. After irradiation, a new set of multi-charged species appeared (Figure 2, bottom panel), which gave, after deconvolution, the expected molecular weight of the photolysis product $\mathbf{8 a}(9259 \mathrm{~m} / \mathrm{z})$. This result confirmed that the photolysis reaction of the ccMO proceeds rapidly and efficiently since no other photolysis by-products were detected. 

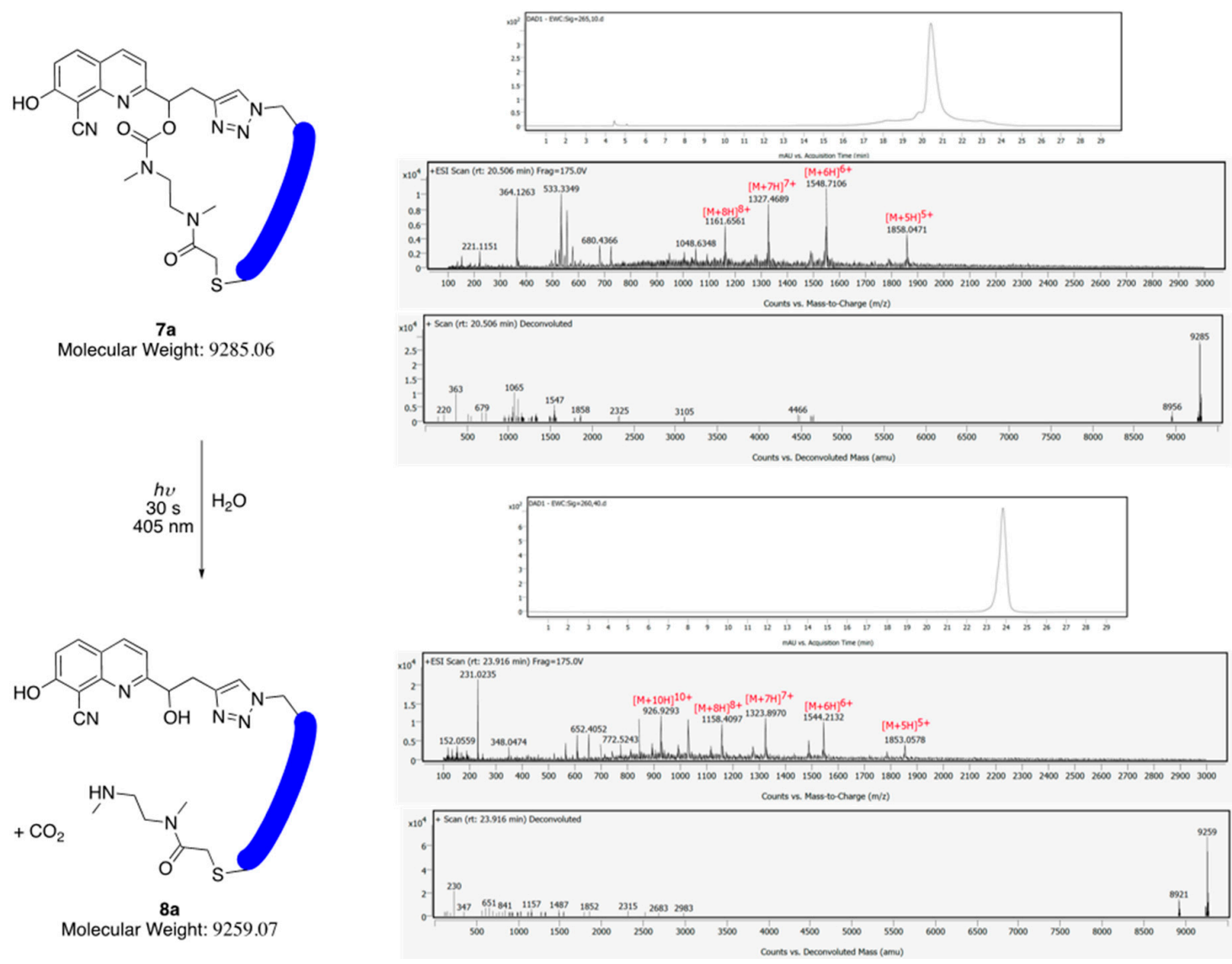

Figure 2. Photolysis reaction of 7a under UV illumination (405 nm, LED) in water monitored by LC-MS. Chromatograms, electrospray ionization high-resolution mass (ESI-HRMS) traces and deconvoluted spectra are given before (top) and after (bottom) photolysis.

\subsection{In-vitro DNA Hybridization}

The crucial property of a successful ccMO is the effective restoration of oligo-hybridization capability upon photoactivation. MOs are typically used to block a complementary sequence of RNA (mRNA, maturation of miRNA, or splicing of pre-mRNA), but they can form a stable duplex with single-stranded DNA (ssDNA) as well $[30,31]$. We investigated the ability of $7 \mathbf{b}$ to bind to a $25-$ mer complementary oligodeoxynucleotide (before and after UV irradiation) using HPLC analysis, following a similar experimental setup to that previously reported [15]. Briefly, separations were carried out using ion-exchange chromatography, and solutions of $\mathbf{7 b}$ (kept in the dark or irradiated with a 405-nm LED) were incubated with the complementary ssDNA at $40{ }^{\circ} \mathrm{C}$ for $30 \mathrm{~min}$ before injection into the HPLC instrument (Figure 3).

Under these experimental conditions, the negatively charged ssDNA (black trace) moved slowly through the ion-exchange column $\left(t_{\mathrm{R}}=11.9 \mathrm{~min}\right.$ ), whereas the neutral ccMO (blue trace) eluted quickly $\left(t_{R}=2.0 \mathrm{~min}\right)$. Note that under these conditions, it is not possible to chromatographically separate the caged and photoactivated $\mathrm{MO}$ since, being both uncharged, they do not interact with the ion-exchange column and elute at the same retention time $(2.0 \mathrm{~min})$. When injecting a mixture of ssDNA and photoactivated $7 \mathbf{b}$ (red trace), a new broad peak appeared $\left(t_{\mathrm{R}}=9.5-10.5 \mathrm{~min}\right)$, corresponding to the duplex between the two species. Without prior photoactivation of $\mathbf{7 b}$ (green trace), only minimal hybridization was observed (a 5.8-fold decrease of the area under the curve (AUC), see Figure 3 caption), due to the residual binding affinity of the ccMO. An analogous result (a 4.1-fold increase from baseline activity) was obtained by Wang and coworkers from the photo-linearization of a circular MO-ntl [15]. Additionally, it has been shown that the basal activity of the ccMO only moderately 
impacts the phenotypical effects in a real biological setup, whereas dramatic outcomes are observed upon linearization [14].

Taken together, the results from the DNA hybridization experiments highlight the potential for the ccMO to be successfully used for the light-triggered modulation of gene expression.

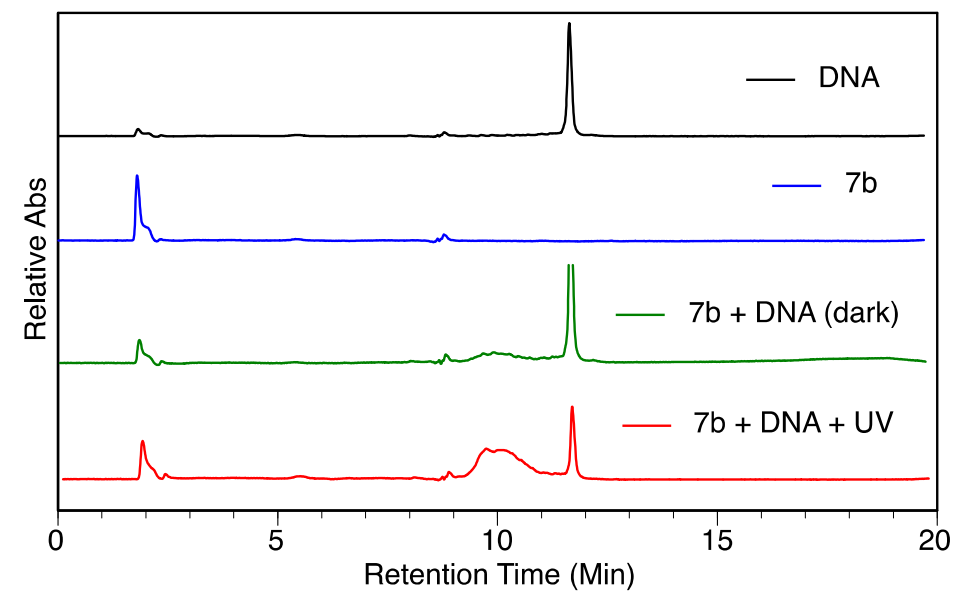

Figure 3. HPLC traces for the DNA hybridization experiments upon photoactivation. The complementary ssDNA sequence to $7 \mathbf{b}$ was used (black line). The ratio of ssDNA to MO used was $2: 1$. A broad peak $\left(t_{\mathrm{R}}=\right.$ 9.5-10.5, AUC = 526) corresponding to the duplex between linearized $7 \mathbf{b}$ and its complementary ssDNA appeared after UV irradiation (red line). Without irradiation (green line) only minor hybridization was detectable $\left(t_{\mathrm{R}}=9.5-10.5\right.$, AUC $\left.=90\right)$.

\section{Discussion}

Manipulating the expression of a gene of interest is a useful approach to study biological processes, and achieving spatiotemporal control over gene knockdown is often required. In this context, photoactivatable antisense reagents, and in particular ccMOs, represent attractive tools compared to other optogenetic approaches [32-34], because of their modularity, efficacy, and simplicity of use in biological preparations. Despite their excellent properties, since their introduction in 2012 [14,15], only a few other works have employed ccMOs in in-vivo experiments [16-19]. We speculate that one of the reasons behind the scarcity of use is related to difficult synthetic preparation.

To overcome these challenges, we designed a ccMO with a key modification (a 1,2,3-triazole ring) in the linker connecting the two ends of the MO. As a result, we synthesized a new photocleavable linker (4) bearing an ethynyl group to be connected to a 5'-azido MO via a click chemistry reaction. The synthetic preparation of this quinoline derivative has several advantages in comparison to our previous method, including a reduced number of steps (5 vs. 11), an improved final yield (28\% vs. 5\%), and increased stability, enabling it to be stored at room temperature while the previous versions (including Chen's) required cold $\left(-30^{\circ} \mathrm{C}\right)$ and moisture-free conditions. In addition, the quinoline-based PPG has superior photochemical properties (faster photolysis kinetics, higher quantum yield, and red-shifted lambda max) compared to the nitroveratryl-based PPG in Chen's linker [25,35]. Compound 4 was effectively conjugated to the $5^{\prime}$-azido- $3^{\prime}$-disulfide-MOs $\mathbf{5 a}$ and $\mathbf{5 b}$ (encoding for the mRNA of the zebrafish genes gad1 and gad2, respectively) through Huisgen 1,3-dipolar azide-alkyne cycloaddition. These new coupling conditions enabled us to generate intermediate linear MOs $\mathbf{6} \mathbf{a}-\mathbf{b}$ faster (reaction time $=1-2 \mathrm{~h}$ ) and in higher purity since most of the reagents and by-products crashed out of the solution and were easily removed by centrifugation. We also optimized the final macrocyclization by using a freshly prepared solution of TCEP (as a disulfide-reducing agent) instead of the resin-bound version used in the previous methods, which requires multiple swelling steps to ensure homogeneous activation. LC-MS was used for the characterization of the final ccMOs and to investigate the products of the photolysis reaction in water (Figure 2). The MS peaks identified 
corresponded to the multi-ionic states of the ccMO and the expected linear photoproduct 8a, resulting from the light-triggered $\mathrm{C}-\mathrm{O}$ bond cleavage and subsequent decarboxylation.

We confirmed that the oligonucleotide binding ability is effectively blocked by the caging strategy and can be promptly restored by illumination, a key property for a photoactivatable construct. The duplex formation between an MO and its complementary ssDNA can be detected by ion-exchange chromatography [15], and we applied the same method to study the ability of our ccMO to hybridize a complementary ssDNA sequence. The minimal duplex formation was detected between the caged morpholino $\mathbf{7 b}$ and its complementary oligodeoxynucleotide (Figure 3, green trace), whereas prior exposure of the solution of $\mathbf{7 b}$ to UV irradiation resulted in a 5.8-fold increase of the MO-ssDNA duplex peak (Figure 3, red trace).

In summary, we described the design and synthesis of photoactivatable MOs to be used for the selective in-vivo photoregulation of gene expression. Compared to previous examples, our ccMOs are easier to prepare and can be designed to target any gene of interest, making the strategy broadly applicable. We believe that these tools will be useful to investigate the function of developmentally important genes, where it is essential to achieve spatiotemporal control over gene knockdown.

\section{Materials and Methods}

\subsection{General Information}

All reagents and solvents were purchased from commercial sources and used without further purification. MOM-CyHQ-CHO was prepared as previously described [27]. All reactions were carried out using glassware except for the MO couplings, which were performed in microcentrifuge tubes. Anhydrous reactions were performed at a positive pressure of dry nitrogen gas. Anhydrous THF was obtained by distillation over $\mathrm{Na}$ /benzophenone. Purifications were carried out using flash chromatography on an Isolera Spektra 4 with Biotage SNAP cartridges packed with KP-Sil silica. ${ }^{1} \mathrm{H}$ NMR and ${ }^{13} \mathrm{C}$ NMR spectra were recorded using a Bruker Avance ${ }^{\mathrm{TM}} \mathrm{III} \mathrm{HD} 500 \mathrm{MHz}$ spectrometer (Billerica, MA, USA). UV spectra for MO quantification were recorded on a Nanodrop 2000c. HPLC was performed on an Agilent Infinity series system with an autosampler and diode array detector. Separations were performed using Zorbax eclipse C-18 reverse phase columns $150 \times 4.6 \mathrm{~mm}$ with $8 \mu \mathrm{m}$ particle size and gradient elution at a flow rate of $0.5 \mathrm{~mL} \mathrm{~min}^{-1}$ : eluent A was acetonitrile and eluent $B$ was water. The analysis started with $2 \%$ of eluent $A$, which was linearly increased up to $100 \%$ over $20 \mathrm{~min}$, and then kept at $100 \%$ for $5 \mathrm{~min}$. HRMS/LC-MS was performed on an Agilent 6540 HD Accurate Mass QTOF/LC/MS (Santa Clara, CA, USA) with electrospray ionization (ESI) using a fragmentor voltage of $175 \mathrm{~V}$.

\subsection{Preparation of Linker 4}

2-(1-hydroxybut-3-yn-1-yl)-7-(methoxymethoxy)quinoline-8-carbonitrile (1). Zinc powder was activated by repeated washing with $0.5 \mathrm{M} \mathrm{HCl}$, followed by $\mathrm{H}_{2} \mathrm{O}$ and $\mathrm{EtOH}$ and dried at $120^{\circ} \mathrm{C}$ for $12 \mathrm{~h}$ prior to use. After activation, $\mathrm{Zn}(107 \mathrm{mg}, 1.65 \mathrm{mmol}, 4 \mathrm{eq})$ and 1,2-dibromoethane $(0.02 \mathrm{~mL}, 0.21 \mathrm{mmol}$, $0.5 \mathrm{eq})$ were suspended in anhydrous tetrahydrofuran (THF) $(5 \mathrm{~mL})$ and sonicated with an ultrasonic bath for $10 \mathrm{~min}$ under nitrogen atmosphere. Propargyl bromide $(0.09 \mathrm{~mL}, 0.83 \mathrm{mmol}, 2 \mathrm{eq})$ was slowly added and the mixture was sonicated for a further $10 \mathrm{~min}$. A solution of MOM-CyHQ-CHO (100 mg, $0.41 \mathrm{mmol}, 1 \mathrm{eq})$ in anhydrous THF $(2 \mathrm{~mL})$ was added and the mixture was sonicated for $1 \mathrm{~h}$ under nitrogen atmosphere. After completion, the reaction was diluted with EtOAc $(30 \mathrm{~mL})$ and filtered over Celite. The filtrate was washed successively with $\mathrm{H}_{2} \mathrm{O}(2 \times 30 \mathrm{~mL})$ and brine $(2 \times 30 \mathrm{~mL})$, dried over $\mathrm{MgSO}_{4}$, and concentrated to dryness. The crude product was purified by column chromatography (hexanes/EtOAc gradient) to yield 1 (78 mg, $0.27 \mathrm{mmol}, 67 \%) .{ }^{1} \mathrm{H}$ NMR $\left(500 \mathrm{MHz}, \mathrm{DMSO}-d_{6}, \delta\right) 8.47$ $(\mathrm{d}, J=8.4 \mathrm{~Hz}, 1 \mathrm{H}), 8.29(\mathrm{~d}, J=8.4 \mathrm{~Hz}, 1 \mathrm{H}), 7.76(\mathrm{~d}, J=8.5 \mathrm{~Hz}, 1 \mathrm{H}), 7.69(\mathrm{~d}, J=8.5 \mathrm{~Hz}, 1 \mathrm{H}), 6.01(\mathrm{~d}$, $J=8.4 \mathrm{~Hz}, 1 \mathrm{H}), 5.61-5.52(\mathrm{~m}, 2 \mathrm{H}), 4.94(\mathrm{t}, J=5.8 \mathrm{~Hz}, 1 \mathrm{H}, \mathrm{O}-\mathrm{H}), 3.49(\mathrm{~s}, 3 \mathrm{H}), 2.91-2.82(\mathrm{~m}, 1 \mathrm{H}), 2.71(\mathrm{~s}$, $1 \mathrm{H}), 2.68(\mathrm{~m}, 1 \mathrm{H}) ;{ }^{13} \mathrm{C}$ NMR $(126 \mathrm{MHz}$, chloroform-d, $\delta): 163.22,162.28,147.16,137.01,133.64,122.91$, 
118.57, $115.74,114.29,99.46,95.10,93.63,80.15,71.30,56.95,29.71,28.24$ (diastereotopic $\mathrm{CH}_{2}$ ); HRMS (ESI-QTOF) $m / z:[\mathrm{M}+\mathrm{H}]^{+}$calcd for $\mathrm{C}_{16} \mathrm{H}_{14} \mathrm{~N}_{2} \mathrm{O}_{3}, 283.1077$; found, 283.1035.

1-(8-cyano-7-(methoxymethoxy)quinolin-2-yl)but-3-yn-1-yl-methyl(2-(methylamino)ethyl)carbamate (2). 1,1'Carbonyldiimidazole (CDI) $(240 \mathrm{mg}, 1.49 \mathrm{mmol}, 7 \mathrm{eq})$ was dissolved in $\mathrm{CH}_{2} \mathrm{Cl}_{2}(6 \mathrm{~mL})$ and the solution was placed into an ice-bath. A solution of $1(60 \mathrm{mg}, 0.21 \mathrm{mmol}, 1 \mathrm{eq})$ in $\mathrm{CH}_{2} \mathrm{Cl}_{2}(4 \mathrm{~mL})$ was added dropwise. The mixture was stirred at $0{ }^{\circ} \mathrm{C}$ for $1 \mathrm{~h}$ and then allowed to reach room temperature and stirred until complete consumption of starting material (30 $\mathrm{min}$, monitored by LC/MS). The reaction was quenched with $\mathrm{H}_{2} \mathrm{O}(20 \mathrm{~mL})$, the organic layer was separated and the aqueous layer was extracted with $\mathrm{CH}_{2} \mathrm{Cl}_{2}(2 \times 5 \mathrm{~mL})$. The organic phases were combined in a round-bottomed flask, cooled by placing the flask into an ice-bath and $N, N^{\prime}$-dimethylethylenediamine $(1.1 \mathrm{~mL})$ was added dropwise. The resulting mixture was stirred at $0{ }^{\circ} \mathrm{C}$ for $2 \mathrm{~h}$, and then at room temperature for $1 \mathrm{~h}$. The reaction was then concentrated to dryness and the crude product was purified by column chromatography $\left(\mathrm{CH}_{2} \mathrm{Cl}_{2} / \mathrm{MeOH}\right.$ gradient) to yield 2 (48 mg, $\left.0.12 \mathrm{mmol}, 57 \%\right) .{ }^{1} \mathrm{H}$ NMR $(500 \mathrm{MHz}$, chloroform- $d, \delta) 8.15$ $(\mathrm{d}, J=8.4 \mathrm{~Hz}, 1 \mathrm{H}), 7.97(\mathrm{~d}, J=9.2 \mathrm{~Hz}, 1 \mathrm{H}), 7.54(\mathrm{~m}, 2 \mathrm{H}), 6.05(\mathrm{t}, J=6.0 \mathrm{~Hz}, 1 \mathrm{H}), 5.45(\mathrm{~s}, 2 \mathrm{H}), 3.64(\mathrm{~s}, 1 \mathrm{H}$, $\mathrm{N}-\mathrm{H}), 3.58(\mathrm{~s}, 3 \mathrm{H}), 3.56-3.47(\mathrm{~m}, 3 \mathrm{H}), 3.15-3.11(\mathrm{~m}, 2 \mathrm{H}), 2.99(\mathrm{~m}, 2 \mathrm{H}), 2.92(\mathrm{~m}, 1 \mathrm{H}), 2.87(\mathrm{q}, J=6.3 \mathrm{~Hz}, 1 \mathrm{H})$, $2.51(\mathrm{~d}, J=31.9 \mathrm{~Hz}, 3 \mathrm{H}), 1.97(\mathrm{~d}, J=12.3 \mathrm{~Hz}, 1 \mathrm{H}) .{ }^{13} \mathrm{C} \mathrm{NMR}(126 \mathrm{MHz}$, chloroform- $d, \delta)$ (rotamers) 162.19, 161.47, 155.95 (155.42), 148.10, 136.77, 133.63, 122.82, 119.08 (118.83), 115.74, 114.68, 99.64, 95.06, 79.86, 75.02, 70.76 (70.67), 56.88, 54.92 (54.01), 48.97 (48.36), 35.81 (35.73), 35.38 (34.89), 24.79. HRMS (ESI-QTOF) $m / z:[\mathrm{M}+\mathrm{H}]^{+}$calcd for $\mathrm{C}_{21} \mathrm{H}_{24} \mathrm{~N}_{4} \mathrm{O}_{4}, 397.1870$; found, 397.1818.

1-(8-cyano-7-(methoxymethoxy)quinolin-2-yl)but-3-yn-1-yl-(2-(2-chloro-N-methylacetamido)ethyl)(methyl) carbamate (3). To a solution of 2 (48 $\mathrm{mg}, 0.12 \mathrm{mmol}, 1 \mathrm{eq})$ in $\mathrm{CH}_{2} \mathrm{Cl}_{2}(5 \mathrm{~mL})$, diisopropylethylamine $(0.04 \mathrm{~mL}, 0.24 \mathrm{mmol}, 2 \mathrm{eq})$ was added dropwise and the mixture was cooled by placing the flask into an ice-bath. A freshly prepared (by treatment of chloroacetic acid with thionyl chloride in $\mathrm{CH}_{2} \mathrm{Cl}_{2}$ at $0{ }^{\circ} \mathrm{C}$ ) $1 \mathrm{M}$ solution of chloroacetylchloride in $\mathrm{CH}_{2} \mathrm{Cl}_{2}(0.24 \mathrm{~mL}, 0.24 \mathrm{mmol}, 2 \mathrm{eq})$ was added dropwise and the resulting mixture was stirred at $0{ }^{\circ} \mathrm{C}$ for $2 \mathrm{~h}$, and then at room temperature for $1 \mathrm{~h}$. The reaction was quenched with $\mathrm{H}_{2} \mathrm{O}(20 \mathrm{~mL})$, extracted with $\mathrm{CH}_{2} \mathrm{Cl}_{2}(3 \times 20 \mathrm{~mL})$, dried over $\mathrm{MgSO}_{4}$, and concentrated to dryness. The crude product was purified by column chromatography (hexanes/EtOAc gradient) to yield 3 (41 mg, $0.09 \mathrm{mmol}, 74 \%) .{ }^{1} \mathrm{H}$ NMR $(500 \mathrm{MHz}$, chloroform- $d, \delta) 8.18(\mathrm{~d}, J=8.5 \mathrm{~Hz}, 1 \mathrm{H}), 7.99$ $(\mathrm{d}, J=9.2 \mathrm{~Hz}, 1 \mathrm{H}), 7.55(\mathrm{dd}, J=9.4,6.7 \mathrm{~Hz}, 2 \mathrm{H}), 6.11-5.98(\mathrm{t}, J=9.8 \mathrm{~Hz}, 1 \mathrm{H}), 5.46(\mathrm{~s}, 2 \mathrm{H}), 4.27-3.94$ $(\mathrm{m}, 2 \mathrm{H}), 3.77-3.63(\mathrm{~m}, 2 \mathrm{H}), 3.59(\mathrm{~s}, 3 \mathrm{H}), 3.57-3.41(\mathrm{~m}, 1 \mathrm{H}), 3.28-3.03(\mathrm{~m}, 7 \mathrm{H}), 2.99(\mathrm{~d}, J=5.8 \mathrm{~Hz}, 2 \mathrm{H})$, 2.09-1.93 (m, 1H). ${ }^{13} \mathrm{C}$ NMR (126 MHz, chloroform-d, $\left.\delta\right)$ (rotamers) 166.78 (166.71), 162.27 (162.17), 161.70 (161.12), 155.76 (155.27), 148.27 (148.08), 136.79 (136.73), 133.63 (133.56), 122.95, 119.78 (118.50), 115.89 (115.73), 114.55, 99.83 (99.75), 95.07, 79.90 (79.61), 75.15, 70.76 (70.62), 56.90, 48.63, 46.79 (46.28, 46.20, 45.77), 41.52 (41.45, 41.00), 36.64 (35.98, 35.94), 35.55 (34.87), 24.88 (24.69). HRMS (ESI-QTOF) $m / z$ : $[\mathrm{M}+\mathrm{H}]^{+}$calcd for $\mathrm{C}_{23} \mathrm{H}_{25} \mathrm{ClN}_{4} \mathrm{O}_{5}, 473.1586$; found, 473.1539.

1-(8-cyano-7-hydroxyquinolin-2-yl)but-3-yn-1-yl-(2-(2-chloro-N-methylacetamido)ethyl)(methyl)carbamate (4). To a solution of $3(30 \mathrm{mg}, 0.06 \mathrm{mmol}, 1 \mathrm{eq})$ in $\mathrm{CH}_{2} \mathrm{Cl}_{2}(2 \mathrm{~mL}), \mathrm{H}_{2} \mathrm{O}(0.1 \mathrm{~mL})$ and trifluoroacetic acid $(0.4 \mathrm{~mL})$ were added. The mixture was stirred at room temperature in the dark for $3 \mathrm{~h}$. After reaction completion (monitored by LC/MS) the mixture was concentrated to dryness and triturated multiple times with THF, affording pure linker $4\left(26 \mathrm{mg}, 0.06 \mathrm{mmol}, 99 \%\right.$ yield). ${ }^{1} \mathrm{H} N \mathrm{MR}(500 \mathrm{MHz}$, chloroform- $d$, ঠ) $8.24(\mathrm{~d}, J=8.4 \mathrm{~Hz}, 0.5 \mathrm{H}$, rotamer), $8.17(\mathrm{~d}, J=5.0 \mathrm{~Hz}, 0.5 \mathrm{H}$, rotamer $), 7.81(\mathrm{dd}, J=18.4,9.0 \mathrm{~Hz}, 1 \mathrm{H})$, $7.37(\mathrm{~d}, J=8.3 \mathrm{~Hz}, 1 \mathrm{H}), 7.07(\mathrm{~d}, J=9.0 \mathrm{~Hz}, 0.5 \mathrm{H}$, rotamer $), 7.01(\mathrm{~d}, J=9.0 \mathrm{~Hz}, 0.5 \mathrm{H}$, rotamer), 6.01 (bs, $J=6.4 \mathrm{~Hz}, 1 \mathrm{H}, \mathrm{OH}), 5.94(\mathrm{dd}, J=7.1,4.5 \mathrm{~Hz}, 1 \mathrm{H}), 4.33-4.25(\mathrm{~m}, 1 \mathrm{H}$, rotamer $), 4.17(\mathrm{~d}, J=4.4 \mathrm{~Hz}$, $1 \mathrm{H}$, rotamer), 4.01-3.86 $(\mathrm{m}, 2 \mathrm{H}), 3.79-3.62(\mathrm{~m}, 2 \mathrm{H}), 3.28(\mathrm{~m}, 3 \mathrm{H}), 3.13-3.08(\mathrm{~m}, 3 \mathrm{H}), 3.05-2.98(\mathrm{~m}, 1 \mathrm{H}$, rotamer), $2.92\left(\mathrm{ddd}, J=17.1,7.1,2.6 \mathrm{~Hz}, 1 \mathrm{H}\right.$, rotamer), $2.03(\mathrm{~m}, 1 \mathrm{H}) .{ }^{13} \mathrm{C}$ NMR $(126 \mathrm{MHz}$, chloroform- $d$, ઈ) (rotamers) 168.54, 163.25, 160.42, 156.99, 147.08, 138.12 (137.86), 134.05 (133.88), 121.80, 118.62 (118.47), 116.20, 94.26 (93.88), 79.47 (78.97), 75.94, 71.17 (71.10), 46.47 (46.30), 46.09, 41.58 (40.85), 36.81 (36.00), 35.87 (34.84), 29.70, 25.36 (25.14). HRMS (ESI-QTOF) $m / z:[\mathrm{M}+\mathrm{H}]^{+}$calcd for $\mathrm{C}_{21} \mathrm{H}_{21} \mathrm{ClN}_{4} \mathrm{O}_{4}, 429.1324$; found, 429.1312 . 


\subsection{Preparation of ccMOs $7 a-b$}

CyHQ-MO-gad1 (6a) and CyHQ-MO-gad2 (6b). The custom 25-mer MO containing 5'-azide and $3^{\prime}$-disulfide amide modifications (5a 5'-AAGGTGCAGAAGACGCCATCAGTCC-3' or 5b 5'-GAAACCAAAACCCGTGTGATGCCAT-3') was obtained from Gene Tools LLC (Philomath, OR, USA) and dissolved in $\mathrm{H}_{2} \mathrm{O}$ to a final concentration of $1 \mathrm{mM}$. The stock solution was sampled $(0.1 \mathrm{~mL}$, $100 \mathrm{nmol}, 1 \mathrm{eq})$, lyophilized in an Eppendorf tube, and re-dissolved in $0.4 \mathrm{~mL}$ of phosphate buffer (0.1 M, pH 8.0). A $50 \mathrm{mM}$ DMSO solution of the photocleavable linker $4(0.02 \mathrm{~mL}, 1 \mu \mathrm{mol}, 10 \mathrm{eq})$ was added to the tube followed by solutions of sodium ascorbate $(0.02 \mathrm{~mL}$ from a $50 \mathrm{mM}$ stock in $\left.\mathrm{H}_{2} \mathrm{O}, 1 \mu \mathrm{mol}, 10 \mathrm{eq}\right)$, copper (I) iodide $(0.02 \mathrm{~mL}$ from a freshly prepared $50 \mathrm{mM}$ stock in DMSO, $1 \mu \mathrm{mol}, 10 \mathrm{eq})$, and tris((1-benzyl-4-triazolyl)methyl)amine (TBTA) (0.02 $\mathrm{mL}$ from a $50 \mathrm{mM}$ stock in DMSO, $1 \mu \mathrm{mol}, 10 \mathrm{eq})$. All operations, including the following one, were carried out in a dark room. The mixture was sonicated in an ultrasonic bath for $2 \mathrm{~min}$ and shaken on a vortexer until the reaction completed (indicated by LC/MS analysis, $1-2 \mathrm{~h}$ ). The precipitate obtained was removed by centrifugation, and the resulting solution was purified on a NAP-5 gel-filtration column (eluting with $2 \mathrm{~mL}$ of Milli-Q water) and lyophilized. The resulting white solid was dissolved in $\mathrm{H}_{2} \mathrm{O}(200 \mu \mathrm{L})$. Acetic acid $(2 \mu \mathrm{L})$ was added to the solution, which was then washed with chloroform $(3 \times 200 \mu \mathrm{L})$ and EtOAc $(2 \times 200 \mu \mathrm{L})$, and then neutralized with $10 \%$ aqueous $\mathrm{NH}_{4} \mathrm{OH}(20 \mu \mathrm{L})$. The solution was lyophilized to dryness, affording the conjugated MO product $\mathbf{6 a}$ or $\mathbf{b}$ as a white solid, which was taken directly to the next step without further purification. 6a HRMS (ESI-QTOF) $m / z$ : [M] ${ }^{+}$calcd for $\mathrm{C}_{338} \mathrm{H}_{515} \mathrm{~N}_{167} \mathrm{O}_{103} \mathrm{~S}_{2} \mathrm{P}_{25} \mathrm{Cl}$, 9439.7029; found (after deconvolution), 9439.3209. 6b HRMS (ESI-QTOF) $\mathrm{m} / \mathrm{z}:[\mathrm{M}]^{+}$calcd for $\mathrm{C}_{338} \mathrm{H}_{515} \mathrm{~N}_{164} \mathrm{O}_{103} \mathrm{~S}_{2} \mathrm{P}_{25} \mathrm{Cl}$, 9397.6828; found (after deconvolution), 9397.2859.

CyHQ-ccMO-gad1 (7a) and CyHQ-ccMO-gad2 (7b). 6a or b was dissolved in $(0.4 \mathrm{~mL})$ of Tris-HCl buffer (0.1 M, pH 8.5) inside an Eppendorf tube. A fresh $15 \mathrm{mM}$ solution of tris(2-carboxyethyl)phosphine (TCEP) $(40 \mu \mathrm{L}, 600 \mathrm{nmol}, 6 \mathrm{eq})$ in Tris- $\mathrm{HCl}$ buffer was added dropwise, and the mixture was shaken on an vortexer for $12 \mathrm{~h}$. All operations, including the following one, were carried out in a dark room. The mixture was purified on a NAP-5 gel-filtration column (eluting with $2 \mathrm{~mL}$ of $\mathrm{H}_{2} \mathrm{O}$ ) and lyophilized, affording pure final compound as a white solid. 7a (25 nmol, 25\% yield over two steps). HRMS (ESI-QTOF) $m / z$ : $[\mathrm{M}]^{+}$calcd for $\mathrm{C}_{334} \mathrm{H}_{507} \mathrm{~N}_{166} \mathrm{O}_{102} \mathrm{SP}_{25}$, 9285.0646; found (after deconvolution), 9285.5066. $7 \mathbf{b}$ (42 nmol, $42 \%$ yield over two steps). HRMS (ESI-QTOF) $m / z$ : [M] ${ }^{+}$calcd for $\mathrm{C}_{334} \mathrm{H}_{507} \mathrm{~N}_{163} \mathrm{O}_{102} \mathrm{SP}_{25}$, 9244.0525; found (after deconvolution), 9244.1692.

\subsection{DNA Hybridization Experiment}

All solutions were prepared in $20 \mathrm{mM}$ phosphate buffer ( $\mathrm{pH}$ 7.2) at a final concentration of $0.05 \mathrm{mM}$. A 25-mer oligodeoxynucleotide (5'-CTTTGGTTTTGGGCACACTACGGTA-3') complementary to 7b (Bioneer Pacific) was used in a 2:1 ratio of ssDNA to MO. Photolysis reactions were performed by irradiating the solution of ccMO for $30 \mathrm{~s}$ with an LED lamp (Cairn OptoLED Lite) at a wavelength of $405 \mathrm{~nm}$ with an average power of $12 \mathrm{~mW}$. Mixtures of the ccMO and ssDNA were incubated in the dark at $40{ }^{\circ} \mathrm{C}$ for $30 \mathrm{~min}$ before HPLC injection. Separations were obtained by ion-exchange chromatography using a DNAPac RP (ThermoFisher) column with gradient elution at a flow rate of $0.6 \mathrm{~mL} \mathrm{~min}^{-1}$ : eluent A was $20 \mathrm{mM}$ phosphate buffer ( $\mathrm{pH}$ 7.2), and eluent B consisted of eluent $\mathrm{A}+$ $2 \mathrm{M} \mathrm{NaCl}$. The analysis started with $100 \%$ of eluent A for $4 \mathrm{~min}$, then B was linearly increased up to $90 \%$ over $11 \mathrm{~min}$, and then remained at $90 \%$ for $2 \mathrm{~min}$. The column was then returned to $100 \% \mathrm{~A}$ over $3 \mathrm{~min}$. Traces were obtained at a wavelength of $280 \mathrm{~nm}$.

Supplementary Materials: The following are available online, ${ }^{1} \mathrm{HNMR}$ and ${ }^{13} \mathrm{C}$ spectra of compounds $1-4 ; \mathrm{HMRS}$ spectra of compounds $6 \mathbf{a}-\mathbf{b}$ and $7 \mathbf{a}-\mathbf{b}$.

Author Contributions: The manuscript was written through the contributions of all authors. All authors have read and agreed to the published version of the manuscript.

Funding: This research was funded by New York University Abu Dhabi. 
Acknowledgments: Part of this work was carried out using Core Technology Platform resources at New York University Abu Dhabi. We thank Naeem Asad and Matthew J O'Connor for helpful discussions.

Conflicts of Interest: The authors declare no conflict of interest.

\section{References}

1. Summerton, J.; Weller, D. Morpholino Antisense Oligomers: Design, Preparation, and Properties. Antisense Nucleic Acid Drug Dev. 1997, 7, 187-195. [CrossRef] [PubMed]

2. Karkare, S.; Bhatnagar, D. Promising nucleic acid analogs and mimics: Characteristic features and applications of PNA, LNA, and morpholino. Appl. Microbiol. Biotechnol. 2006, 71, 575-586. [CrossRef] [PubMed]

3. Hudziak, R.M.; Barofsky, E.; Barofsky, D.F.; Weller, D.L.; Huang, S.-B.; Weller, D.D. Resistance of Morpholino Phosphorodiamidate Oligomers to Enzymatic Degradation. Antisense Nucleic Acid Drug Dev. 1996, 6, $267-272$. [CrossRef] [PubMed]

4. Paul, S.; Caruthers, M.H. Synthesis of Phosphorodiamidate Morpholino Oligonucleotides and Their Chimeras Using Phosphoramidite Chemistry. J. Am. Chem. Soc. 2016, 138, 15663-15672. [CrossRef] [PubMed]

5. Summerton, J. Morpholino antisense oligomers: The case for an RNase H-independent structural type. Biochim. Biophys. Acta 1999, 1489, 141-158. [CrossRef]

6. Heasman, J.; Kofron, M.; Wylie, C. $\beta$ Catenin Signaling Activity Dissected in the Early Xenopus Embryo: A Novel Antisense Approach. Dev. Biol. 2000, 222, 124-134. [CrossRef]

7. Nasevicius, A.; Ekker, S.C. Effective targeted gene 'knockdown' in zebrafish. Nat. Genet. 2000, 26, $216-220$. [CrossRef]

8. Aung-Htut, M.T.; McIntosh, C.S.; West, K.A.; Fletcher, S.; Wilton, S.D. In Vitro Validation of Phosphorodiamidate Morpholino Oligomers. Molecules 2019, 24, 2922. [CrossRef]

9. Shestopalov, I.A.; Sinha, S.; Chen, J.K. Light-controlled gene silencing in zebrafish embryos. Nat. Chem. Biol. 2007, 3, 650-651. [CrossRef]

10. Ouyang, X.; Shestopalov, I.A.; Sinha, S.; Zheng, G.; Pitt, C.L.W.; Li, W.-H.; Olson, A.J.; Chen, J.K. Versatile Synthesis and Rational Design of Caged Morpholinos. J. Am. Chem. Soc. 2009, 131, 13255-13269. [CrossRef]

11. Tallafuss, A.; Gibson, D.; Morcos, P.; Li, Y.; Seredick, S.; Eisen, J.; Washbourne, P. Turning gene function $\mathrm{ON}$ and OFF using sense and antisense photo-morpholinos in zebrafish. Development 2012, 139, 1691-1699. [CrossRef] [PubMed]

12. Tomasini, A.J.; Schuler, A.D.; Zebala, J.A.; Mayer, A.N. PhotoMorphs: A novel light-activated reagent for controlling gene expression in zebrafish. Genesis 2009, 47, 736-743. [CrossRef]

13. Deiters, A.; Garner, R.A.; Lusic, H.; Govan, J.M.; Dush, M.; Nascone-Yoder, N.M.; Yoder, J.A. Photocaged Morpholino Oligomers for the Light-Regulation of Gene Function in Zebrafish and Xenopus Embryos. J. Am. Chem. Soc. 2010, 132, 15644-15650. [CrossRef] [PubMed]

14. Yamazoe, S.; Shestopalov, I.A.; Provost, E.; Leach, S.D.; Chen, J.K. Cyclic Caged Morpholinos: Conformationally Gated Probes of Embryonic Gene Function. Angew. Chem. Int. Ed. 2012, 51, 6908-6911. [CrossRef] [PubMed]

15. Wang, Y.; Wu, L.; Wang, P.; Lv, C.; Yang, Z.; Tang, X. Manipulation of gene expression in zebrafish using caged circular morpholino oligomers. Nucleic Acids Res. 2012, 40, 11155-11162. [CrossRef] [PubMed]

16. Yamazoe, S.; Liu, Q.; McQuade, L.E.; Deiters, A.; Chen, J.K. Sequential gene silencing using wavelength-selective caged morpholino oligonucleotides. Angew. Chem. Int. Ed. 2014, 53, 10114-10118. [CrossRef] [PubMed]

17. Yamazoe, S.; McQuade, L.E.; Chen, J.K. Nitroreductase-activatable morpholino oligonucleotides for in vivo gene silencing. Acs Chem. Biol. 2014, 9, 1985-1990. [CrossRef]

18. Griepenburg, J.C.; Rapp, T.L.; Carroll, P.J.; Eberwine, J.; Dmochowski, I.J. Ruthenium-Caged Antisense Morpholinos for Regulating Gene Expression in Zebrafish Embryos. Chem Sci 2015, 6, 2342-2346. [CrossRef]

19. O'Connor, M.J.; Beebe, L.L.; Deodato, D.; Ball, R.E.; Page, A.T.; VanLeuven, A.J.; Harris, K.T.; Park, S.; Hariharan, V.; Lauderdale, J.D.; et al. Bypassing Glutamic Acid Decarboxylase 1 (Gad1) Induced Craniofacial Defects with a Photoactivatable Translation Blocker Morpholino. Acs Chem. Neurosci. 2019, 10, $266-278$. [CrossRef]

20. Kool, E.T. Circular Oligonucleotides: New Concepts in Oligonucleotide Design. Annu. Rev. Biophys. Biomol. Struct. 1996, 25, 1-28. [CrossRef] 
21. Seyfried, P.; Eiden, L.; Grebenovsky, N.; Mayer, G.; Heckel, A. Photo-Tethers for the (Multi-)Cyclic, Conformational Caging of Long Oligonucleotides. Angew. Chem. Int. Ed. 2017, 56, 359-363. [CrossRef] [PubMed]

22. Richards, J.L.; Seward, G.K.; Wang, Y.-H.; Dmochowski, I.J. Turning the 10-23 DNAzyme On and Off with Light. ChemBioChem 2010, 11, 320-324. [CrossRef]

23. Griepenburg, J.C.; Ruble, B.K.; Dmochowski, I.J. Caged oligonucleotides for bidirectional photomodulation of let-7 miRNA in zebrafish embryos. Bioorg. Med. Chem. 2013, 21, 6198-6204. [CrossRef] [PubMed]

24. Zhang, L.; Liang, D.; Wang, Y.; Li, D.; Zhang, J.; Wu, L.; Feng, M.; Yi, F.; Xu, L.; Lei, L.; et al. Caged circular siRNAs for photomodulation of gene expression in cells and mice. Chem Sci 2018, 9, 44-51. [CrossRef] [PubMed]

25. Davis, M.J.; Kragor, C.H.; Reddie, K.G.; Wilson, H.C.; Zhu, Y.; Dore, T.M. Substituent effects on the sensitivity of a quinoline photoremovable protecting group to one- and two-photon excitation. J. Org. Chem. 2009, 74, 1721-1729. [CrossRef] [PubMed]

26. Rostovtsev, V.V.; Green, L.G.; Fokin, V.V.; Sharpless, K.B. A Stepwise Huisgen Cycloaddition Process: Copper(I)-Catalyzed Regioselective "Ligation" of Azides and Terminal Alkynes. Angew. Chem. Int. Ed. 2002, 41, 2596-2599. [CrossRef]

27. Asad, N.; Deodato, D.; Lan, X.; Widegren, M.B.; Phillips, D.L.; Du, L.; Dore, T.M. Photochemical Activation of Tertiary Amines for Applications in Studying Cell Physiology. J. Am. Chem. Soc. 2017, 139, 12591-12600. [CrossRef]

28. Ma, J.; Rea, A.C.; An, H.; Ma, C.; Guan, X.; Li, M.D.; Su, T.; Yeung, C.S.; Harris, K.T.; Zhu, Y.; et al. Unraveling the mechanism of the photodeprotection reaction of 8-bromo- and 8-chloro-7-hydroxyquinoline caged acetates. Chem. Eur. J. 2012, 18, 6854-6865. [CrossRef]

29. Klan, P.; Solomek, T.; Bochet, C.G.; Blanc, A.; Givens, R.; Rubina, M.; Popik, V.; Kostikov, A.; Wirz, J. Photoremovable protecting groups in chemistry and biology: Reaction mechanisms and efficacy. Chem. Rev. 2013, 113, 119-191. [CrossRef]

30. Liu, Y.; Irving, D.; Qiao, W.; Ge, D.; Levicky, R. Kinetic Mechanisms in Morpholino-DNA Surface Hybridization. J. Am. Chem. Soc. 2011, 133, 11588-11596. [CrossRef]

31. Gong, P.; Wang, K.; Liu, Y.; Shepard, K.; Levicky, R. Molecular Mechanisms in Morpholino-DNA Surface Hybridization. J. Am. Chem. Soc. 2010, 132, 9663-9671. [CrossRef] [PubMed]

32. Wang, X.; Chen, X.; Yang, Y. Spatiotemporal control of gene expression by a light-switchable transgene system. Nat. Methods 2012, 9, 266-269. [CrossRef] [PubMed]

33. Shimizu-Sato, S.; Huq, E.; Tepperman, J.M.; Quail, P.H. A light-switchable gene promoter system. Nat. Biotechnol. 2002, 20, 1041-1044. [CrossRef] [PubMed]

34. Ye, H.; Baba, M.D.-E.; Peng, R.-W.; Fussenegger, M. A Synthetic Optogenetic Transcription Device Enhances Blood-Glucose Homeostasis in Mice. Science 2011, 332, 1565-1568. [CrossRef] [PubMed]

35. Fedoryak, O.D.; Dore, T.M. Brominated hydroxyquinoline as a photolabile protecting group with sensitivity to multiphoton excitation. Org. Lett. 2002, 4, 3419-3422. [CrossRef] [PubMed]

Sample Availability: Samples of the compounds are not available from the authors.

(C) 2020 by the authors. Licensee MDPI, Basel, Switzerland. This article is an open access article distributed under the terms and conditions of the Creative Commons Attribution (CC BY) license (http://creativecommons.org/licenses/by/4.0/). 